\title{
PENGARUH KEPEMILIKAN INSTITUSIONAL TERHADAP IMPLEMENTASI STRATEGI PROSPEKTOR DAN DEFENDER
}

\author{
Adi Prasetyo \\ Fakultas Ekonomi dan Bsinis Universitas Muhammadiyah Malang \\ E-mail: aprasetyo21@yahoo.com
}

\begin{abstract}
The purpose of this study is to proof that the institution stock holders have a significant effect on implementation of typology organizational strategy. Furthermore, it showed that the domination of institution stock holders have significant influence on implementation of prospector typology and defender strategy. Institutional stock holders measured by percentage of stock holders were published by the Indonesian Capital Market Directory (ICMD). On the other hand, in order to determine prospector typology and defender strategy, the researcher used four indicators as proxy, such as: KARPEN, PBV, CETA, and CEMVE.
\end{abstract}

Keywords: Institutional Stock Holder, Prospector typology, Defender strategy

\begin{abstract}
Abstrak
Tujuan dari penelitian ini adalah untuk membuktikan bahwa pemegang saham institusi memiliki pengaruh yang signifikan terhadap pelaksanaan tipologi strategi orgazational. Bahkan, menunjukkan bahwa dominasi pemegang saham institusi memiliki pengaruh yang signifikan terhadap pelaksanaan tipologi pencari dan strategi defender. Pemegang saham institusional diukur dengan persentase pemegang saham yang diterbitkan oleh Indonesian Capital Market Directory (ICMD). Sisi lain, untuk menentukan dari tipologi prospektor dan strategi bek kita menggunakan empat indikator sebagai proxy, seperti: Karpen, PBV, CETA, dan CEMVE.
\end{abstract}

Kata Kunci: Kepemilikan Pemegang Saham, Prospektor, Defender

Seorang manajer perusahaan senantiasa dihadapkan pada tuntutan untuk selalu memberikan yang terbaik bagi perusahaan. Suatu hal yang harus dilakukan oleh seorang manajer adalah menjaga pertumbuhan profit dari tahun ke tahun. Untuk mencapai tujuan tersebut, seorang manajer dihadapkan pada berbagai pilihan aktivitas, baik organisasional maupun finansial. Dalam hal organisasional, seorang manajer diharapkan dapat mengendalikan aktivitas perusahaan sehingga perusahaan dapat mencapai tujuan yang telah ditetapkan sebelumnya. Sementara itu, dari sisi finansial seorang manajer dapat melakukan kegiatan pendanaan, investasi, maupun pembagian deviden yang semua itu dimaksudkan untuk menjaga pertumbuhan keuntungan.

Apapun aktivitas yang akan dilakukan oleh seorang manajer pasti membutuhkan keputusan untuk memulai tindakan tersebut. Setiap keputusan yang dibuat oleh manajerakan 
berdampak pada aktivitas berikutnya. Apalagijika keputusan tersebut menyangkut masalahkeuangan, sepertiinvestasi misalnya. Keputusan investasi mencakup pengalokasian dana yang cukup besar, baik yang berasal dari dalam maupun dari luar perusahaan. Keputusan investasi sangat penting karena akan mempengaruhi keberhasilan perusahaan dan merupakan inti dari seluruh aktivitas keuangan (Gitman, 2000; Brealy dan Myers, 2000). Sementara itu, Jensen dan Meckling (1976) menyatakan bahwa keputusan investasi dapat berperan sebagai mekanisme pertukaran antara kepemilikan dan nilai perusahaan.

Keputusan investasi dapat diimplementasikan bila terdapat dukungan dana yang cukup, baik internal maupun eksternal. Ketersediaan dana secara internal dapat berasal keuntungan operasional perusahaan, maupun dari aktivitas investasi dan pendanaan. Sementara itu, ketersediaan dana secara eksternal dapat berasal dari investor maupun kreditor. Melalui sumber-sumber pembiayaan yang ada, perusahaan dapat memilih alternatif yang ada dalamrangka menentukan struktur modal yang tepat bagi perusahaan (Haruman, 2008). Dalam perspektif manajerial, keputusan struktur modal tidak hanya menentukan komposisi sumber internal dan eksternal, tetapi juga komposisi kepemilikan internal, institusional dan publik. Dengan demikian, fungsi pendanaan merupakan langkah untuk menentukan sumber dana yang optimal dalammendanai berbagai alternatif investasi, sehingga dapat memaksimalkan nilai perusahaan.

Nilai perusahaan yang semakin tinggi dapat meningkatkan minat investor untuk memiliki sahamperusahaan tersebut. Mengingat nilai perusahaan yang tinggi dapat memberikan return yang tinggipula. Kondisi ini tentu saja menguntungkan bagi manajer per- usahaan, karena dia dianggap mampu mengelola perusahaan dengan baik. Di sisi lain, meningkatnya nilai perusahaan akan berdampak pada meningkatnya harga saham menimbulkan banyak pihak yang berminat untuk memiliki saham perusahaan, baik institusi maupun publik. Hal ini tentu saja menimbulkan konflik kepentingan.

Konflik kepentingan yang dimaksud adalah perbedaan kepentingan antara manajer dengan investor. Dalam teori keagenan (agency theory) dinyatakan bahwa seorang manajer cenderung mengutamakan kepentingan pribadi daripada kepentingan perusahaan (Jensen dan Meckling, 1976). Demikian pula perbedaan kepentingan antara pemegang saham institusi dengan pemegang saham publik. Akibat perbedaan kepentingan ini juga akan menimbulkan perbedaan dalam menetukan strategi untuk mencapai tujuan perusahaan.

Berdasarkan uraian di atas, secara eksplisit dinyatakan bahwa struktur kepemilikan perusahaan dapat mempengaruhi keputusan yang berkaitan dengan keuangan. Dalam kenyataannya didunia usaha, keputusan seperti ini biasanya diambil melalui RUPS (Rapat Umum Pemegang Saham) yang dilaksanakan satu tahun sekali. Termasuk keputusan yang terkait dengan strategi yang hendak diimplementasikan pada tahun berikutnya.

Keberadaan pemegang saham mayoritas biasanya akan menentukan ke arah mana perusahaan hendak dituju. Berdasarkan visi dan misi perusahaan yang ditetapkan melalui RUPS, maka selanjutnya dijabarkan oleh manajemen dalam bentuk strategi yang akan diimplementasikan oleh manajemen. Dengan demikian, kepemilikan saham oleh institusi (yang biasanya merupakan pemegang saham mayoritas) akan mempengaruhi implementasi strategi perusahaan. 
Pemetaan strategi organisasional oleh Miles dan Snow (1978), dinyatakan bahwa terdapat empat tipologi strategi organisasional yang digunakan oleh perusahaan dalam memenangkan persaingan (competitive advantage). Ke empat tipologi tersebut adalah: prospector, analyzer, reactor, dan defender. Tipologi prospector dan tipologi defender merupakan tipologi strategi organisasional yang berada pada dua titik extreem, artinya ke dua tipologi ini berbeda secara nyata (signifikan).

Tipologi prospector mengembangkan keunggulan bersaing melalui pengembangan keunikan produk (differetiation strategy) berdasarkan persepsi consumer; pertumbuhan penjualan dan perluasan pangsa pasar (Hamid, 1999). Sementara itu, tipologi strategi organisasional defender mengembangkan keunggulan bersaing melalui penawaran produk dengan harga yang lebih murah (cost leadership strategy) berdasarkan persepsi konsumen, pasar yang stabil (dalam artimempertahankan pangsa pasar yang telah dicapai).

Berdasarkan penjelasanfenomenadiatas, diperoleh gambaran bahwa tipologi strategi organisasional merupakan pilihan strategi dalammembangun keunggulan bersaing. Pilihan strategi merupakan keputusan yang tidak bebas dari campurtangan pemegang saham (owners). Oleh karena itu, penelitian ini berusaha memberikan bukti bahwa kepemilikan institusional berpengaruh terhadap implementasi strategi prospektor dan defender.

Tujuan penelitian ini adalah untuk memberikan bukti empiris apakah terdapat pengaruh kepemilikan institusional terhadap implementasi strategi prosepktor dan defender. Mengingat bahwa kepemilikan mayoritas saham suatu perusahaan akan berakibat pada pola kebijakan umum perusahaan.

\section{Metode Penelitian}

Variabel dependen dalam penelitian ini adalah implementasi strategi prospektor dan defender. Penentuan sampel untuk digolongkan ke dalam prospektor atau defender digunakan 4 indikator, yaitu: rasio jumlah karyawan dibagi dengantotal penjualan (KARPEN), price to book value (PBV) (Ittner dkk., 1997); rasio capital expenditure dibagimarket value of equity (CEMVE), dan rasio capital expenditure to total asset (CETA) (Skinner, 1993; Kallapur dan Trombley, 1999). Selanjutnya untuk mereduksi bias pengukuran, nilaikeempat indikator tersebut dianalisis menggunakan common factor analysis.

Variabel independen yang digunakan dalam penelitian adalah rasio kepemilikan institusi yang terdapat dalam laporan tahunan perusahaan yang terdaftar di Bursa Efek Indonesia. Pengukuran rasio ini sudah tersedia dalam laporan tahunan tersebut, berupa prosentase kepemilikan yang dilaporkan. Angka prosentase kepemilikan inilah yang dijadikan ukuran untuk variabel independen.

Perusahaan yang dipilih sebagai sampel adalah perusahaan-perusahaan go public yang terdaftar di Bursa Efek Indonesia. Pemilihan sampel menggunakan metode classified random sampling yaitu pemilihan sampel perusahaan untuk klasifikasi tertentu. Klasifikasi yang diterapkan dalam pemilihan sampel berdasarkan variabel dependen dalam penelitian ini. Perusahaan yang terpilih sebagai sampel adalah perusahaan yang terseleksimelalui analysis factor dalam penentuan perusahaan yang menerapkan strategi prospektor dan defender.

Berdasarkan hasil seleksi analisis faktor diperoleh 60 perusahaan yang terpilih sebagai sampel, yaitu perusahaan-perusahaan yang memenuhi kriteria setelah faktor-faktor yang 
diturunkan dari indikator dijumlahkan dan diurutkan dari yang besar ke yang kecil. Perusahaan dengan jumlah faktor besar dikelompokkan sebagai perusahaan yang menerapkan strategi prospektor, sebaliknya perusahaan yang memiliki jumlah faktor kecil dikelompokkan sebagai perusahaan yang menerapkan strategi defender.

\section{Hasil Penelitian dan Pembahasan}

Tabel 1 dan 2 menyajikan ringkasan hasil analisis statistik deskriptif dari variabel yang digunakan dalam penelitian ini. Data dalam tabel 1 dan 2 terdiri dari dua kelompok, yaitu: statistik deskriptifuntuk kelompok prospektor dan statistik deskriptif untuk defender. Dalam tabel 1 disajikan statistik deskriptif untuk kelompok prospektor, yang terdiri dari rata-rata (mean), deviasi standar (standard deviation), jumlah (sum), maksimum (maximum), dan minimum. Demikian juga halnya untuk tabel 2 , di mana dalam tabel 2 ini disajikan statistik deskriptifuntuk kelompok perusahaan yang menerapkan strategi defender.

Berdasarkan tabel 1 dapat diperoleh gambaran, bahwa variabel faktor yang merupa- kan indikator dari variabel strategi prospektor: mean $(0,1967)$, standard deviation $(0,2056)$, maximum $(0,7477)$, dan minimum (-0.0155). Sementara itu, variable kepemilikan yang merupakan indikator dari variabel kepemilikan institusi: mean $(0,7558)$, standard deviation $(0,1450)$, maximum (0,9521), dan minimum (0.5011).

Berdasarkan tabel 2 dapat diperoleh gambaran, bahwa variabel faktor yang merupakan indikator dari variabel strategi prospektor: mean $(-0,2403)$, standard deviation (0,1620), maximum $(-0,1552)$, dan minimum (-0.8294). Sementara itu, variabel kepemilikan yang merupakanindikator dari variabelkepemilikan institusimean $(0,6669)$, standard deviation $(0,1450)$, maximum $(0,9750)$, dan minimum (0.0314).

Berdasarkan fakta-fakta tersebut, semua indikator yang terkait dengan faktor penerapan strategi semua menunjukkan bahwa prospektor lebih tinggi daripada defender, mulai dari mean, standard deviation, maximum dan minimum. Hal ini searah dengan apa yang telah diprediksi/ dihipotesiskan, yaitu bahwa perusahaan yang menerapkan strategi prospektor memiliki indika-

Tabel 1. Prospektor Descriptive Statistics

\begin{tabular}{llrrrrr}
\hline & $\mathrm{N}$ & Minimum & Maximum & \multicolumn{1}{c}{ Sum } & \multicolumn{1}{c}{ Mean } & Std. Deviation \\
\hline Factor & 30 & -.0155 & .7477 & 5.9016 & .196721 & .2053061 \\
Kepemilikan & 30 & .5011 & .9521 & 22.6755 & .755850 & .1450565 \\
Valid N (listwise) & 30 & & & & & \\
\hline
\end{tabular}

Tabel 2. Defender Descriptive Statistics

\begin{tabular}{llrrrrr}
\hline & N & Minimum & Maximum & \multicolumn{1}{l}{ Sum } & Mean & Std. Deviation \\
\hline Factor & 30 & -.8294 & -.1552 & -7.2091 & -.240304 & .1620760 \\
Kepemilikan & 30 & .0314 & .9750 & 20.0087 & .666957 & .2142673 \\
Valid N (listwise) & 30 & & & & & \\
\hline
\end{tabular}


tor yang lebih tinggi daripada perusahaan yang menerapkan strategi defender. Sementara itu, dari sisi variable kepemilikan institusi, ada satu nilai defender yang lebih tinggi daripada prospektor, yaitu: nilai maksimum, di mana nilai maksimum untuk perusahaan yang menerapkan strategi defender $(0,9750)$ dan perusahaan prospektor $(0,9521)$.

Variabel faktor merupakan representasi dari implementasi strategi, baik strategi prospektor maupun defender. Dimana untuk mendapatkan nilai-nilai faktor tersebut diperoleh melalui rasio-rasio keuangan, seperti: rasio jumlah karyawan dibagi dengan total penjualan (KARPEN), price to book value (PBV) (Ittner dkk., 1997); rasio capital expenditure dibagi market value of equity (CEMVE), dan rasio capital expenditure to total asset (CETA) (Skinner, 1993; Kallapur dan Trombley, 1999). Selanjutnya untuk mereduksi bias atas pengukuran (rasio pengukuran), maka nilai ke empat indikator tersebut dianalisis menggunakan common factor analysis. Adapun hasil analisis faktor atas ke empat indikator tersebut dibahas pada sesi seleksi pengelom- pokan perusahaan sampel ke dalam perusahaan yang mengimplementasikan strategi prospektor dan defender berikut ini.

Prosedur analisis faktor digunakan untuk mengidentifikasi perusahaan bertipologi prospektor dan perusahaan bertipologi defender. Prosedur ini digunakan karena adanyadimensi-dimensilatent (tersembunyi). Prosedur analisis faktor dapat mengidentifikasi dimensi laten. Atas variabel-variabel asli (Hair dkk., 1995). Empat variable asli sebagai indikator atau proksi atas strategi orgainsasional yang digunakan dalam penelitian ini, yaitu: rasio jumlah karyawan dibagi dengan total penjualan (KARPEN), price to book value (PBV); rasio capital expenditure dibagi market value of equity (CEMVE), dan rasio capital expenditure to total asset (CETA).

Tabel 3 menunjukkan hasil commonfactor analysis terhadap empat indikator strategi organisasional. Common factor analysis adalah model faktor, di mana faktorfaktor didasarkan pada pengurangan matrik korelasi. Communalities adalah jumlah va-

Tabel 3. Common Factor Analysis Variabel Indikator Strategi Organisasional

A. Communalities dari empat variabel indikator:

$\begin{array}{lccll}\begin{array}{l}\text { Variabel } \\ \text { KARPEN }\end{array} & \text { PBV } & \text { CETA } & \text { CEMVE } & \\ \text { Communalities } & 0,566 & 0,966 & 0,966 & 0,565 \\ \text { Eigenvalues untuk } & \text { pengurangan } & \text { matrik korelasi: } & & \\ \text { Faktor } & 1 & 2 & 3 & 4 \\ \text { Eigenvalues } & 1,933 & 1,130 & 0,870 & 0,068\end{array}$

C. Korelasi antara faktor dengan empat indicator:

$\begin{array}{lllll}\text { Indikator } & \text { PBV } & \text { CETA } & \text { CEMVE } & \text { KARPEN } \\ \text { Faktor } 1 & -0,023 & 0,508 & 0,508 & -0,018 \\ \text { Faktor2 } & 0,665 & 0,033 & 0,021 & 0,665\end{array}$


rian variabel-variabel asli yang terbagi kepada semua variabel yang termasuk dalamanalisis (Hair dkk., 1995).

Di dalam tabel 3 diperlihatkan nilaicommunalities indicator individual dari strategi organisasional. Nilai tersebut digunakan untuk menentukan jumlah faktor representasi atas variabel-variabel asli. Jumlah ke empat nilai communalities tersebut adalah sebesar 3,063. Untuk mencapainilai tersebut dibutuhkan dua faktor yang mempunyai nilai $e i$ genvalues diatas satu, yaitu faktor satu $(1,933)$ dan faktor dua $(1,130)$ dengan jumlah 3,063. Hal ini sesuai dengan rule of thumb bahwa jumlah faktor yang digunakan sebagai variable representasi adalah sebanyak faktor yang mempunyai nilai eigenvalues sama atau lebih dari satu.

Dalamkasus ini, dua faktor dibutuhkan untuk menjelaskan hubungan timbal balik di antara indikator. Faktor satu berkaitan dengan CETA dan CEMVE, di mana loading atas keduanya masing-masing 0,982 dan 0,983. Sementara itu faktor ke dua berkaitan dengan PBV dan KARPEN dengan loading keduanya sama yaitu 0,751 . Setelah ditetapkan faktor satu dan faktor dua, maka hasil kedua faktor tersebut dijumlahkan sehingga diperoleh angka indeks dari dua faktor yang disebut faktor_sum.

Penentuan perusahaan bertipologi prospektor atau defender didasarkan pada penjumlahan indek keduafaktor (faktor1+faktor2).
Penjumlahan angka indeks ini (fakt_sum) kemudian diperingkat. Seperempat peringkat pertama diidentifikasi sebagai perusahaan bertipologi prospektor dan seperempat peringkat terakhir diidentifikasi sebagai perusahaan bertipologi defender. Melalui prosedur ini berhasil diidentifikasi masingmasing 30 perusahaan bertipologi prospektor dan 30 perusahaan bertipologi defender, dari 116 perusahaan yang datanya lengkap.

Setelah diperoleh perusahaan bertipologi prospektor dan defender, langkah selanjutnya adalah dilakukan regresi, dimana variable dependennya adalah tipologi strategi perusahaan (yakni: prospector dan defender). Sehingga variable dependen digunakan dummy variable, mengingat prospector dan defender merupakan strategi organisasional yang berseberangan. Sementara itu, variable independennya adalah kepemilikan institusi atas suatu perusahaan.

Proses analisis (regresi) disajikan berikut, Penelitian ini menguji apakah kepemilikan perusahaan oleh institusi berpengaruh terhadap implementasi strategi prospektor dan defender. Hipotesis yang diajukan adalah bahwa kepemilikan institusi berpengaruh positif terhadap implementasi strategi prospektor dan defender. Mengingat, bahwa variabeldependen dalam penelitian ini merupakan dua variable yang berseberangan, maka untuk variabel ini digunakan variabel dummy. Pembentukan variabel dum-

Tabel 4. Hasil Regresi

\begin{tabular}{|c|c|c|c|c|c|c|}
\hline & \multirow{2}{*}{ Model } & \multicolumn{2}{|c|}{ Unstandardized Coefficients } & \multicolumn{3}{|l|}{ Standardized } \\
\hline & & B & Std. Error & Beta & & \\
\hline 1 & (Constant) & .040 & .253 & & .156 & .8 \\
\hline & kepemilikan & .647 & .344 & .240 & 1.882 & $.0 t$ \\
\hline
\end{tabular}

a. Dependent Variable: dummy 
my dilakukan melalui seleksi sampel. Tabel 4 menggambarkan hasil pengujian hipotesis pertama (Ha- ${ }_{1}$ dan Ha-2) kepemilikan institusi berpengaruhpositifterhadapimplementasistrategi prospektor dan implementasi strategidefender.

Berdasarkan tabel4, dapat diperoleh informasi bahwa penelitiberhasil membuktikan adanya pengaruh positif dari variable kepemilikan institusiterhadap implementasi strategi prospector dan defender. Hal ini bisa dibuktikan dengan koefisien beta $(\beta)$ pada variabel kepemilikan institusi sebesar $=0,647$ $(64,70 \%)$ denganp-value (signifikansi) sebesar 0,065. Angka 64,70\% menunjukkan bahwa kepemilikan institusi mempengaruhi sebesar 64,70\% terhadap implementasi strategi, sedangkan 35,30\% dipengaruhi oleh faktor lain. Sementara itu, angka 0,065 menunjukkan tingkat signifikansi pengaruh tersebut, yaitu signifikan pada level 10\%. Dengan demikian, hasil penelitian ini sesuai dengan yang diprediksikan.

\section{Penutup}

Penelitianinidilakukandalamupayamemberikan buktiempiris, bahwa kepemilikan institusi atas suatu perusahaan memberikan pengaruh terhadap keputusan, maupun kebijakan-kebijakan yang diterapkan dalam perusahaan. Termasuk dalam implementasi strategi yang digunakan oleh perusahaan. Berdasarkan hasil penelitian diperoleh kesimpulan bahwa implementasi strategi oleh perusahaan dipengaruhiprosentase kepemilikan institusiatas perusahaan.

Hal tersebut dapat dijelaskan, bahwa strategi-strategi yang akanditerapkan dalamperusahaan diproses melalui Rapat Umum Pemegang Saham(RUPS). Dalam rapat umum pemegang saham(RUPS) diputuskan langkahlangkah strategis yangharus dilakukan olehma- najemen perusahaan. Tentu saja, pemegang saham yang memiliki saham terbanyak memiliki suara mayoritas dalam menetapkan keputusan-keputusan. Dengan demikian, hasil penelitian ini mendukung fenomena sosial tersebut.

Hasil penelitian ini memiliki beberapa keterbatasan. Pertama, sample yang digunakan tidak dipilih secara random dan dibatasi hanya perusahaan manufaktur saja. Keterbatasan ini membuat hasil penelitian tidak dapat digunakan sebagai dasar generalisasiuntuk semua jenis perusahaan.

Kedua, sample yang terpilih dalampenelitian ini relatif kecil, yaitu 30 perusahaan bertipologi prospector dan 30 perusahaan bertipologi defender. Keterbatasan inimenyebabkan power of test-nya menjadi lemah.

Ketiga, penelitian ini belum mempertimbangkan perusahaan-perusahaan yang mendapat regulasi khusus dari pemerintah, sehingga dapat menyebabkan kesalahan dalam menentukan tipologi strategi organisasional perusahan.

\section{DAFTAR PUSTAKA}

Brealy, R and John Myers. 2000. Principles of Corporate Finance ( $6^{\text {th }}$ edition). MCGraw Hill. New York.

Gitman, L.J. 2000. Principles of management Finance ( $9^{\text {th }}$ Edition). Addison Wasler. USA.

Hamid, Abd. 1999. Studi terhadap Strategi Prospektor dan Defender dan Hubungannya dengan Harga Saham: Analisis dengan Pendekatan Life Cycle Theory. Kumpulan Makalah SNA2. Malang.

Haruman, Tendi. 2008. Pengaruh Struktur Kepemilikan terhadap Keputusan Keuangan dan Nilai Perusahaan: Survey pada Perusahaan 
Manufaktur di Bursa Efek Indonesia. Kumpulan Makalah SNA 11. Pontianak.

Ittner, Ch, David Larcker and Madhav Rajan. 1997. The Choice of Performance Measures in Annual Bonus Contracts. The Accounting Review, Vol. 72, No. 2 (April), pp: $231-255$.

Jensen, MichaelC., and William H Meckling. 1976. Theory of the Firm: Managerial Behavior, Agency Costs and Ownership Structure. Journal of Financial Economics, 3, pp: $82-137$.

Kallapur, Sanjay, and Mark Trombley. 1999. The Association Between Investment Opportunity Set Proxies and Realized Growth. Journal of Business and Finance and Accounting, Vol. 26, pp: $505-519$.

Miles, Raymond and Charles C Snow. 1978. Organizational: Strategy, Structure and Process ( $3^{\text {rd }}$ Edition). McGraw Hill Publishing. New York.

Porter, E. Michael. 1980. Competitive Strategy: Technique for Analyzing Industries Competitors ( $2^{\text {nd }}$ Edition). FreePress. New York.

Skinner, Douglas. 1993. The Investment Opportunity Set and Accounting Procedures Choice. Journal of Accounting and Economics, Vol. 16, pp: 407 455. 